\title{
Genetic Variability and Correlation Studies on Nendran (AAB) Ecotypes of Banana (Musa spp.)
}

\author{
C. Rajamanickam* \\ Department of Horticulture, Agricultural College and Research Institute, \\ Madurai, Tamil Nadu, India \\ *Corresponding author
}

\section{A B S T R A C T}

\section{Keywords}

Banana,

Heritability,

Genetic advance,

Genetic and

Phenotypic

coefficient of

variation

Article Info

Accepted:

26 September 2020

Available Online:

10 October 2020

\begin{abstract}
The present study on genetic variability and correlation studies on Nendran ecotypes of banana (Musa spp.) was carried out at Instructional Farm, College of Agriculture, Vellayani, Thiruvanthapuram, Kerala to study for their genetic variability and correlation among the nendran ecotypes of banana. The genotypic and phenotypic coefficient of variation, heritability, genetic advance and correlation coefficient were estimated for seventeen traits which included plant height, number of suckers per plant, number of leaves per plant, leaf width, days taken from planting to shooting, bunch weight, bunch length, hand weight, number of fingers per bunch, number of fingers per hand, length, girth, weight and volume of finger, ripe fruit weight, sugar:acid ratio and pulp weight. A remarkable variability was observed among the collections for these characters. All the characters showed the highest estimates of broad sense heritability whereas genetic advance as percentage of mean recorded higher in traits such as volume of finger, finger weight, ripe fruit weight, pulp weight and number of fingers per bunch. The value of high PCV, GCV, heritability and genetic advance makes it a prime character for the direct selection. Weight of finger, bunch weight, volume of finger and number of fingers per bunch showed high genetic advance and high heritability are the other important characters which have to be considered for selection of the ecotypes.
\end{abstract}

\section{Introduction}

The primary object of crop improvement programme is a critical assessment of genetic variability existing in that particular crop and the extent to which the character to be improved is heritable. Burton (1952) has pointed out that calculating the genetic coefficient of variation along with heritability can assess a best picture of the amount of advancement to be expected by selection.
Ramanujan and Thirumalachar (1967) suggested that heritability estimate in the broad sense will be reliable, if accompanied by a high genetic advance. Johnson et al., (1955) and Swarup and Changle (19677) also considered that heritability estimates along with genetic gain are useful and reliable than heritability estimates along with predicting the selection response. Effectiveness of selection based on phenotypic performance can be more useful and reliable only if 
selection is based on heritability estimates along with genetic gain. Above all these knowledge, the present investigation to extent the critical assessment on the biometrical studies on seventeen characters of twelve Nendran ecotypes of banana (Musa spp.) were studied.

\section{Materials and Methods}

The present investigation was carried out at Department of Pomology and Floriculture, College of Agriculture, Vellayani, Thiruvananthapuram, Kerala. Twelve Nendran ecotypes of banana were collected from different parts of Kerala and Tamil Nadu and planted at Instructinal Farm, College of Agriculture. This experiment was laid out in completely randomized block design (CRD) with 12 treatments and five replications as per the method suggested by Panse and Sukhatme (1967). Suckers of twelve Nendran ecotypes of banana almost uniform in size were used for the study and planted at a spacing of $2.0 \mathrm{x}$ $2.0 \mathrm{~m}$. The cultural practices were followed as per the Package of Practices Recommendations (KAU, 1996). The observations on vegetative traits such as plant height $(\mathrm{cm})$, number of suckers per plant, number of leaves per plant, leaf width $(\mathrm{cm})$, days taken for planting to shooting (days) and bunch traits such as number of fingers per hand, number of fingers per bunch, bunch weight $(\mathrm{kg})$, hand weight $(\mathrm{kg})$, bunch length (cm) and finger characters such as length $(\mathrm{cm})$, girth $(\mathrm{cm})$, weight $(\mathrm{g})$ and volume of finger (cc), ripe fruit weight (g), sugar:acid ratio, pulp weight (g) were recorded. Biometrical data were collected and statistically analysed as per the method was suggested by Fischer, (1960). From the analysis of variance, genetic parameters like phenotypic and genotypic coefficient of variation (PCV and GCV) was estimated by the method of Burton, (1952) where as broad sense habitability $(\mathrm{H} \%)$ by Burton and de
Vane, (1953), genetic advance as percentage of mean (GA \%) by Allard (1960) and correlation (r) by the method of Al-Jibouri et al., (1960) (Table 1).

\section{Results and Discussion}

The phenotypic and genotypic coefficient of variation for seventeen morphological characters of twelve Nendran ecotypes of banana was studied. Phenotypic coefficient of variation $(\mathrm{PCV})$ is higher than their respective genotypic coefficient of variation (GCV) for all the characters, which reflects the influence of environment on the phenotypic expression of these characters. Significant differences were recorded among the various ecotypes of Nendran banana. Range and general mean for each character with wide variations in mean values are presented in Table 2. The highest range of variation were shown in the traits such as number of fingers per bunch, finger weight, volume of finger, ripe fruit weight, plant height, days taken from planting to shooting, sugar:acid ratio, leaf width and pulp weight, whereas the lowest range of variation recorded in the traits such as number of suckers per plant, number of leaves per plant, leaf width, number of fingers per hand, bunch weight, finger length, hand weight and finger girth.

Generally, phenotypic coefficient of variation (PCV) found higher than the genotypic component and the extent of latter component also showed that they are mostly heritabile in nature (Table 3 ). In the present study, PCV ranged from 7.64 per cent (leaf width) to 49.38 per cent (number of fingers per bunch). The highest PCV recorded in the traits such as number of fingers per bunch (49.38\%), followed by number of suckers per plant (47.48 \%), bunch weight (44.22\%), hand weight $(42.63 \%)$, volume of finger (39.48 $\%$ ), ripe fruit weight $(39.48 \%)$, pulp weight $(39.41 \%)$ and finger weight $(37.95 \%)$. The 
lowest PCV was observed in leaf width (7.64 $\%)$, followed by plant height $(12.10 \%)$, number of leaves per plant $(13.60 \%)$ and days taken for planting to shooting (14.01\%). Sreerangaswamy et al., (1980) obtained that the higher PCV was noticed in culinary and dessert type banana. GCV is a better tool to understand useful variability, as it is free from the environmental components. GCV helps in comparison and measurement of genetic variability among different characters. In the present study results revealed that GCV ranged from 7.24 per cent (leaf width) to 48.42 per cent (number of fingers per bunch). The highest GCV was recorded in the characters such as number of fingers per bunch (48.42\%), followed by number of suckers per plant (48.18\%), bunch weight $(42.93 \%)$, hand weight $(42.63 \%)$, ripe fruit weight $(39.32 \%)$, pulp weight $(39.24 \%)$, volume of finger $(39.23 \%)$ and finger weight (37.82 \%). The lowest GCV was observed in leaf width $(7.24 \%)$, followed by number of leaves per plant $(12.01 \%)$ and days taken form planting to shooting (13.85\%). Rajeevan and Geetha (1982) stated that higher PCV and GCV were obtained in bunch weight, number of fingers per bunch, number of hands per bunch, finger length and finger weight among 40 banana cultivars of Kerala. Moderate values of PCV and GCV and very high heritability with moderate GAM was observed for pseudostem height revealing relatively low influence of environment on this trait Kavitha et al., (2008) and Sawant et. al., (2016) in banana.

Heritability in broad sense gives the amount of heritable potion of a character. Characters possessing high heritability can be improved directly through selection as they are less affected by the environment. In the present study results revealed that all the traits exhibited high heritability which ranged from 69.60 per cent (number of leaves per plant) to 99. 31 per cent (finger weight). The traits such as weight of finger $(99.31 \%)$, volume of finger $(99.22 \%)$, ripe fruit weight $(99.22 \%)$, pulp weight (99.12\%), plant height (98.46 $\%$ ), days taken from planting to shooting (97.62 \%), number of fingers per bunch (96.13\%), length of finger $(95.51 \%)$, bunch length $(94.43 \%)$, bunch weight (94.27\%), leaf width $(90.04 \%)$, number of suckers per plant $(90.00 \%)$, girth of finger $(89.35 \%)$, weight of hand $(89.24 \%)$ and sugar/acid ratio $(88.63 \%)$ recorded the higher heritability.

Table.1 Cultivars, banana types, ploidy and genomic composition of banana clones

\begin{tabular}{|c|l|l|c|c|}
\hline Sl. No. & \multicolumn{1}{|c|}{ Ecotypes } & Type & Ploidy & Genomic Composition \\
\hline 1. & Vellayani Nendran & Dessert /cooking & $3 \mathrm{x}$ & AAB \\
\hline 2. & Padalamurian & Dessert /cooking & $3 \mathrm{x}$ & $\mathrm{AAB}$ \\
\hline 3. & Myndoli & Dessert /cooking & $3 \mathrm{x}$ & $\mathrm{AAB}$ \\
\hline 4. & Chengazhikodan & Dessert /cooking & $3 \mathrm{x}$ & $\mathrm{AAB}$ \\
\hline 5. & Attu Nendran & Dessert /cooking & $3 \mathrm{x}$ & $\mathrm{AAB}$ \\
\hline 6. & Kaliethan & Dessert /cooking & $3 \mathrm{x}$ & $\mathrm{AAB}$ \\
\hline 7. & Koonoor Ethan & Dessert /cooking & $3 \mathrm{x}$ & $\mathrm{AAB}$ \\
\hline 8. & Mysore Ethan & Dessert /cooking & $3 \mathrm{x}$ & $\mathrm{AAB}$ \\
\hline 9. & Zanzibar & Dessert /cooking & $3 \mathrm{x}$ & $\mathrm{AAB}$ \\
\hline 10. & Quintal banana & Dessert /cooking & $3 \mathrm{x}$ & $\mathrm{AAB}$ \\
\hline 11. & Changanasseri Nendran & Dessert /cooking & $3 \mathrm{x}$ & $\mathrm{AAB}$ \\
\hline 12. & Manjeri Nendran & Dessert /cooking & $3 \mathrm{x}$ & $\mathrm{AAB}$ \\
\hline
\end{tabular}


Table.2 Phenotypic variability of twelve Nendran ecotypes of banana

\begin{tabular}{|l|c|l|c|}
\hline Characters & Mean \pm S.E. & \multicolumn{1}{|c|}{ Range } & CD at 5\% \\
\hline Plant height (cm) & $314.71 \pm 11.0$ & $387.0-264.6$ & $\mathbf{2 4 . 3}$ \\
\hline Number of leaves per plant & $8.96 \pm 0.30$ & $11.6-7.2$ & $\mathbf{0 . 7 0}$ \\
\hline Leaf width (cm) & $69.49 \pm 1.58$ & $81.3-64.0$ & $\mathbf{3 . 2}$ \\
\hline Number of suckers per plant & $10.75 \pm 1.40$ & $24.8-5.40$ & $\mathbf{3 . 1}$ \\
\hline Days taken for planting to shooting (days) & $247.0 \pm 9.90$ & $303.6-174.2$ & $\mathbf{2 1 . 8}$ \\
\hline Bunch weight (kg) & $13.658 \pm 1.7$ & $30.4-6.5$ & $\mathbf{3 . 7}$ \\
\hline Number of fingers per hand & $10.451 \pm 0.6$ & $14.2-7.6$ & $\mathbf{1 . 4}$ \\
\hline Number of fingers per bunch & $52.717 \pm 7.4$ & $102.8-18.4$ & $\mathbf{1 6 . 3}$ \\
\hline Finger weight (g) & $254.54 \pm 27.3$ & $507.4-180.1$ & $\mathbf{6 1 . 2}$ \\
\hline Bunch length (cm) & $59.445 \pm 3.4$ & $81.74-47.90$ & $\mathbf{7 . 5}$ \\
\hline Finger length (cm) & $23.737 \pm 1.6$ & $37.3-17.8$ & $\mathbf{3 . 6}$ \\
\hline Finger girth (cm) & $13.612 \pm 0.6$ & $17.6-10.3$ & $\mathbf{1 . 4}$ \\
\hline Volume of fruit (cc) & $248.12 \pm 28.2$ & $503.9-173.0$ & $\mathbf{6 2 . 0}$ \\
\hline Ripe fruit weight $(\mathbf{g})$ & $248.12 \pm 26.2$ & $480.2-156.5$ & $\mathbf{5 1 . 4}$ \\
\hline Pulp weight (g) & $186.44 \pm 21.1$ & $362.0-115.5$ & $\mathbf{4 6 . 5}$ \\
\hline Sugar: acid ratio & $60.706 \pm 3.8$ & $79.7-31.9$ & $\mathbf{8 . 4 0}$ \\
\hline Hand weight (g) & $\mathbf{2 . 4 7 3} \pm \mathbf{0 . 3}$ & $\mathbf{4 . 5}-\mathbf{1 . 5 0}$ & $\mathbf{0 . 6}$ \\
\hline
\end{tabular}

Table.3 PCV, GCV, ECV, heritability and genetic advance at 5\% of the morphological characters of twelve Nendran ecotypes of banana

\begin{tabular}{|c|c|c|c|c|}
\hline Characters & GCV $(\%)$ & $\begin{array}{l}\text { PCV } \\
(\%)\end{array}$ & $\begin{array}{c}\text { Heritability } \\
(\%)\end{array}$ & $\begin{array}{c}\text { Genetic Advance at } \\
5 \%\end{array}$ \\
\hline Plant height $(\mathrm{cm})$ & 12.008 & 12.101 & 98.50 & 24.545 \\
\hline Number of leaves per plant & 11.349 & 13.604 & 69.60 & 19.505 \\
\hline Leaf width $(\mathrm{cm})$ & 7.245 & 7.635 & 90.00 & 14.161 \\
\hline Number of suckers per plant & 45.189 & 47.476 & 90.60 & 88.606 \\
\hline Days taken for planting to shooting (days) & 13.847 & 14.014 & 97.60 & 28.184 \\
\hline Bunch weight $(\mathrm{kg})$ & 42.932 & 44.219 & 94.30 & 85.867 \\
\hline Hand weight $(\mathrm{g})$ & 40.276 & 42.634 & 89.20 & 78.380 \\
\hline Number of fingers per hand & 20.467 & 22.868 & 80.10 & 37.735 \\
\hline Number of fingers per bunch & 48.419 & 49.385 & 96.10 & 97.791 \\
\hline Finger weight $(\mathrm{g})$ & 37.823 & 37.954 & 99.30 & 97.791 \\
\hline Bunch length $(\mathrm{cm})$ & 19.663 & 20.234 & 94.40 & 39.361 \\
\hline Finger length $(\mathrm{cm})$ & 23.841 & 24.394 & 95.50 & 47.998 \\
\hline Finger girth $(\mathrm{cm})$ & 15.500 & 16.397 & 89.40 & 30.181 \\
\hline Volume of fruit (cc) & 39.323 & 39.478 & 99.20 & 80.686 \\
\hline Ripe fruit weight (g) & 39.323 & 39.478 & 99.20 & 80.686 \\
\hline Pulp weight (g) & 39.240 & 39.413 & 99.00 & 80.479 \\
\hline Sugar: acid ratio & 21.589 & 22.932 & 88.60 & 41.868 \\
\hline
\end{tabular}


Table.4 Genotypic correlation coefficient of variation of twelve Nendran ecotypes of banana

\begin{tabular}{|c|c|c|c|c|c|c|c|c|c|c|c|c|c|c|c|c|c|}
\hline & 1 & 2 & 3 & 4 & 5 & 6 & 7 & 8 & 9 & 10 & 11 & 12 & 13 & 14 & 15 & 16 & 17 \\
\hline 1 & 1.000 & 0.513 & 0.559 & 0.173 & 0.621 & 0.623 & 0.435 & 0.406 & -0.078 & 0.230 & 0.107 & -0.134 & -0.072 & -0.072 & -0.117 & 0.406 & 0.253 \\
\hline 2. & & 1.000 & 0.631 & 0.788 & 0.092 & -0.095 & -0.143 & -0.366 & 0.546 & -0.565 & 0.600 & 0.181 & 0.541 & 0.541 & 0.495 & 0.730 & 0.503 \\
\hline 3. & & & 1.000 & 0.733 & 0.149 & 0.297 & 0.434 & 0.125 & 0.669 & -0.050 & 0.706 & 0.584 & 0.679 & 0.679 & 0.587 & 0.478 & 0.742 \\
\hline 4. & & & & 1.000 & -0.008 & -0.166 & -0.027 & -0.339 & 0.796 & -0.411 & 0.828 & 0.697 & 0.798 & 0.798 & 0.695 & 0.419 & 0.707 \\
\hline 5. & & & & & 1.000 & 0.311 & 0.468 & 0.523 & -0.472 & 0.285 & -0.235 & -0.368 & -0.457 & -0.457 & -0.570 & 0.117 & -0.229 \\
\hline 6. & & & & & & 1.000 & 0.631 & 0.792 & -0.171 & 0.755 & -0.083 & 0.069 & -0.165 & -0.165 & -0.203 & 0.020 & 0.302 \\
\hline 7. & & & & & & & 1.000 & 0.878 & -0.044 & 0.623 & 0.060 & 0.020 & -0.028 & -0.028 & -0.127 & 0.032 & 0.201 \\
\hline 8. & & & & & & & & 1.000 & -0.391 & 0.780 & -0.316 & -0.204 & -0.378 & -0.378 & -0.449 & -0.192 & 0.043 \\
\hline 9. & & & & & & & & & 1.000 & -0.368 & 0.925 & 0.844 & 1.000 & 1.000 & 0.983 & 0.396 & 0.860 \\
\hline 10. & & & & & & & & & & 1.000 & -0.290 & -0.042 & -0.363 & -0.363 & -0.380 & -0.167 & -0.021 \\
\hline 12. & & & & & & & & & & & & 1.000 & 0.849 & 0.849 & 0.802 & 0.095 & 0.856 \\
\hline 13. & & & & & & & & & & & & & 1.000 & 1.000 & 0.981 & 0.389 & 0.867 \\
\hline 14. & & & & & & & & & & & & & & 1.000 & 0.981 & 0.389 & 0.867 \\
\hline 15. & & & & & & & & & & & & & & & 1.000 & 0.378 & 0.830 \\
\hline 16. & & & & & & & & & & & & & & & & 1.000 & 0.378 \\
\hline 17. & & & & & & & & & & & & & & & & & 1.000 \\
\hline \multicolumn{18}{|c|}{$\begin{array}{l}\text { *-Significant at } 5 \text { per cent } \\
\text { 1.Plant height }(\mathrm{cm}) \\
\text { 2.Number of leaves per plant } \\
\text { 3.Leaf width }(\mathrm{cm}) \\
\text { 4.Number of suckers per plant } \\
\text { 5.Days taken for planting to shooting (days) } \\
\text { 6.Bunch weight }(\mathrm{kg})\end{array}$} \\
\hline
\end{tabular}


Table.5 Phenotypic correlation coefficient of variation of twelve Nendran ecotypes of banana

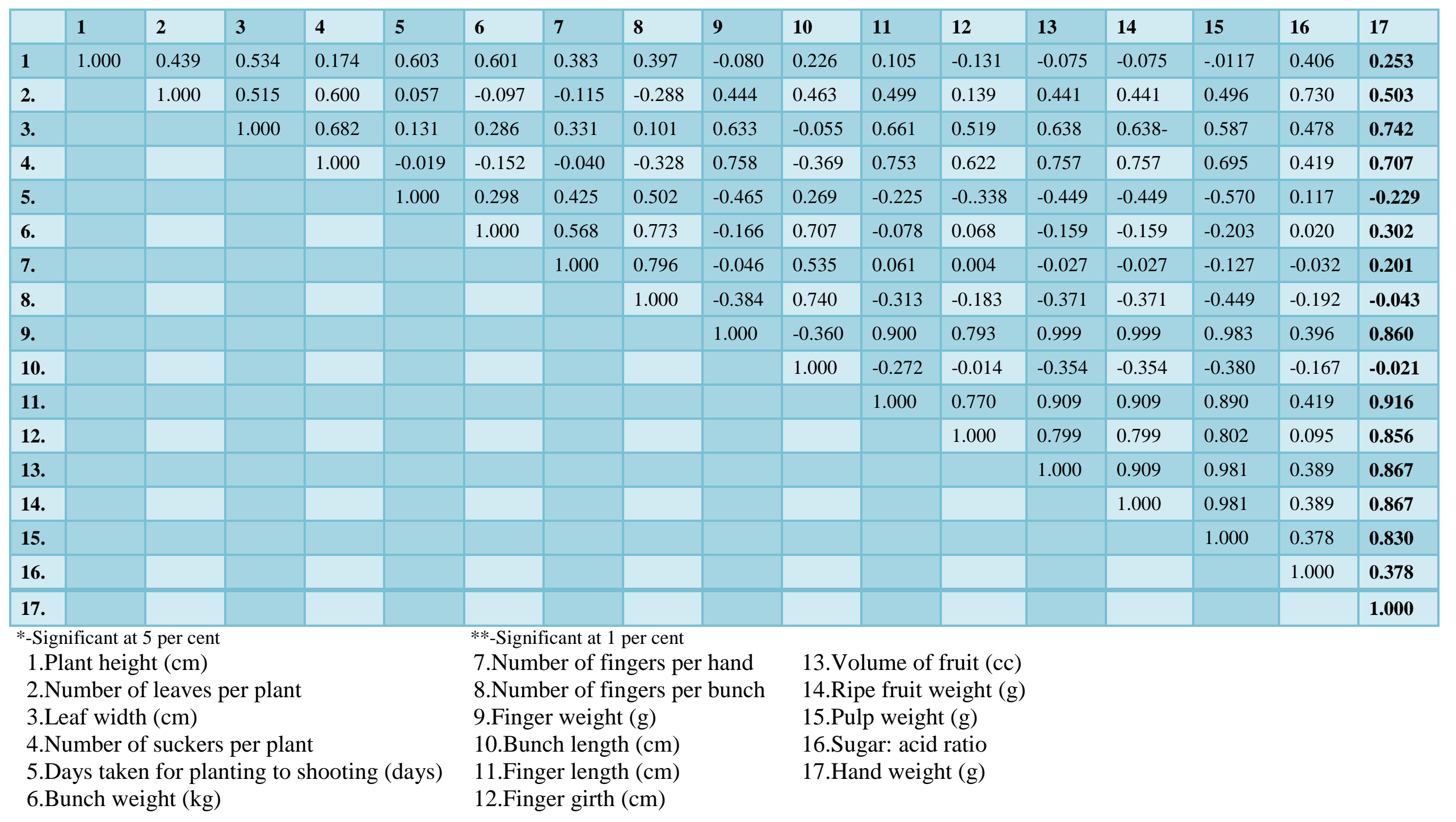


Their relatively higher values of heritability imply that large proportion of phenotypic variance was attributable to the genotypic variance. The high heritability was also reported for leaves at flowering and number of hands per bunch (Rajeevan and Geetha, 1982), leaf area per plant and volume of finger (Valsalakumari and Nair, 1986), bunch length (Rosamma and Namboodiri, 1990) and bunch weight (Uma et al., 2000).

In the present investigation results revealed that there was a wide range of variation among the characters for their genetic advances varied from 14.16 per cent (leaf width) to 97.79 per cent (finger weight; number of fingers per bunch). The genetic advance as percent of mean recorded the higher in the traits such as finger weight and number of fingers per bunch (97.79 $\%)$, number of suckers per plant $(88.61 \%)$, bunch weight $(85.67 \%)$, volume of fruit and ripe fruit weight $(80.67 \%)$, pulp weight $(80.48$ $\%)$ and hand weight $(78.38 \%)$, whereas the lowest genetic advance as percentage of mean was observed in the traits such as lead width (14.16\%), number of leaves per plant (19.50 $\%)$, plant height $(24.55 \%)$ and days taken for planting to shooting $(28.18 \%)$. Many of the traits registered higher genetic advance it might be due to these characters are additive types reported by Johnson et al., (1955).

Number of fingers per bunch with the high value of PCV, GCV and heritability coupled with genetic advance indicated that these characters are predominantly controlled by additive gene action. This is supported by the hypothesis proposed by Panse (1957). Heritability along with genetic advance is more useful than heritability alone in predicting the results and effect of selecting the best individuals (Johnson et al., 1955). Uma et al., (2000) reported that plant height with very high value of heritability and moderate value of genetic advance, revealing relatively low influence of environment on this trait of silk ecotypes of banana.

Correlation provides information on the nature and extent of association between characters in a population. When selection procedure is applied on a trait, the population under selection is improved not only for traits but also for other traits associated with it. This facilitates simultaneous improvement of two or more characters. Therefore, analysis of yield in terms of phenotypic, genotypic and environmental correlation coefficients of component characters leads helps in understanding characters that can form the basis of selection (Table 4 and 5). In the present study results revealed that bunch weight had significant phenotypic correlation with plant height, days taken from planting to shooting, leaf width, number of fingers per bunch, hand weight, finger weight and bunch length. Significant genotypic correlation with bunch weight was seen for plant height, days taken for planting to shooting, leaf width, number of fingers per bunch, bunch length, hand weight and finger weight. The highly significant phenotypic correlation of bunch weight with number of fingers per bunch obtained in the present study is in agreement with the findings of Rosamma and Namboodiri (1990). Significant association of bunch weight of banana with fingers per hand at genotypic level was reported by Krishnan and Shanmugavelu (1983) and Rosamma and Namboodiri (1990). Positive significant phenotypic and genotypic correlation of plant height with bunch weight as seen in the present studies was earlier reported by Krishnan and Shanmughavelu (1983). Significant positive association of number of fingers per bunch with bunch weight at phenotypic and genotypic level is in agreement with the findings of Krishnan and Shanmugavelu (1983) and Rosamma and Namboodiri (1990). The positive phenotypic and genotypic association with number of fingers per bunch and bunch length obtained in the present study is in conformity with the findings of Sunilkumar (1997) in banana. He also stated that significant phenotypic and genotypic correlation of girth of finger with length of finger and weight of finger showed the positive correlation with girth of finger and length of finger. 


\section{References}

Al-Jibouri, H.A., Miller, P.A. and Robinson, H.F. 1958. Genotypic and environmental variances and covariance in upland cotton cross of inter specific origin. Agron J. 50: 633 - 636.

Allard, R.W. 1960. Principles of Plant Breeding. John Wiley \& Sons Inc., New York. 460 p.

Burton, C. W. 1952. Quantitative inheritance I grasses. Proc. 6th Int. Grassland Congr. 1: $277-283$.

Burton, G.W. and deVane, E.H. 1953. Estimating heritability in tall fescue (Festuca arundinacea) from replicated clonal material. Agron J. 45: 478 - 481.

Fischer, R.A. 1960. The design of experiments. Hafner Publishing Co., Inc. New York. p. 50-67.

Johnson, H.W., Robinson, H.F. and Comstock, R.E. 1955. Estimates of genetic and environmental variability in soyabeans. Agron J. 47: 314 - 318.

KAU. 1996. Package of Practices Recommendation, Kerala Agricultural University, Vellanikkara, Thrissur.

Kavitha, P.S, Balamohan, T.N, Kumar, N. and Veeraragavathatham, D. 2008. Genetic variability studies in banana hybrids. The Asian Journal of Horticulture, 3 (1): $265-269$.

Krishnan, B. M. and Shanmugavelu, K. G. 1983. Correlation studies in banana cv. Robusta. South Indian Hort. 31(2): 110111.

Panse V.G. 1957. Genetics of quantitative characters in relation to plant breeding. Indian J. Genet. 17: 18 - 27.

Panse V.G. and Sukhatme, P.V. 1967. Statistical methods for agricultural workers. $2^{\text {nd }}$ edition. ICAR, New Delhi.
Rajeevan, P.K. and Geetha, C. K. 1982. Variability studies in banana. South Indian. Hort. 34: 197 - 200.

Ramanujam, S. and Thirumalachar, D.K. 1967. Genetic variability of certain characters in red pepper (Capsicum annuum, L.). Mysore J. Agric. 1: 30 - 36.

Rosamma C. A. and Namboodiri, K.M.N. 1990. Genetic analysis of yield in banana, Agric Res. J. Kerala. 28: 1- 8.

Sawant, S.B, Dalvi, V.V, Bhave, S.G, Haldankar, P.M. and Mahadik, S.G. 2016. Genetic variability of banana (Musa spp.) in West Coastal Zone of India. Electronic Journal of Plant Breeding, 7(4): 1144-1150.

Sreerangaswamy, S.R., Samandamurthy, S. and Murugan, M. 1980. Genetic analysis in banana. National seminar on banana production technology. TNAU, Coimbatore. (eds. C.R. Muthukrishnana and J.B.M Abdulkhader). p. 67-70.

Sunilkumar, K. 1997. Selection of superior types of Kaliethan (Musa AAB group) Nendran. M.Sc. (Hort.) thesis, Kerala Agricultural University, Thrissur.

Swarup, V. and Chaugle, D.S. 1967. Studies on genetic variability in sorgham. 1. Phenotypic variations and its heritable components in some quantitative characters contributing towards yield. Indian J. Genet. 22: 31 - 36.

Uma, S., Dayarani, M., Singh, H.P., Shyam, B. and Sathiamoorthy, S. 2000. Studies on genetic variability in banana silk subgroup (AAB). Indian J. Hort. 57 (2): $106-109$.

Valsalakumari, P.K. and Nair, P.C.S. 1986. Genetic variability in banana. Agric Res. J. Kerala. 24 (1): 66- 72.

\section{How to cite this article:}

Rajamanickam, C. 2020. Genetic Variability and Correlation Studies on Nendran (AAB) Ecotypes of Banana (Musa spp.). Int.J.Curr.Microbiol.App.Sci. 9(10): 3223-3230. doi: https://doi.org/10.20546/ijcmas.2020.910.385 